\title{
Primary cerebral lymphoma presenting with cranial diabetes insipidus
}

\author{
A.W. Patrick, ${ }^{1}$ I.W. Campbell, ${ }^{2}$ B. Ashworth ${ }^{1}$ and A. Gordon ${ }^{3}$ \\ ${ }^{1}$ Medical Neurology Unit, Northern General Hospital, Edinburgh, ${ }^{2}$ Medical Unit, Victoria Hospital, Hayfield \\ Road, Kirkcaldy, Fife and ${ }^{3}$ Department of Neuropathology, Western General Hospital, Edinburgh, UK.
}

\begin{abstract}
Summary: A 30 year old woman with an 8-year history of thirst and polyuria was found to have cranial diabetes inspidus. There were no neurological abnormalities at presentation but she subsequently developed diverse signs and died 26 months later. Autopsy revealed a diagnosis of diffuse primary cerebral lymphoma. Cranial diabetes insipidus with otherwise minimal abnormality of hypothalamic/pituitary function has not previously been reported as a presentation of this neoplasm.
\end{abstract}

\section{Introduction}

Primary cerebral lymphoma is a rare neoplastic disorder which may involve the brain diffusely and characteristically follows a rapidly progressive course.

We report the case of a young woman, who presented with diabetes insipidus several years before developing further neurological abnormalities, and in whom a diagnosis of widespread primary cerebral lymphoma was made at autopsy.

\section{Case report}

A 30 year old woman presented with an 8-year history of thirst and polyuria. She reported secondary amenorrhoea since discontinuing the combined oral contraceptive pill 3 years previously but had no other symptoms and was receiving no medication. Clinical examination was unremarkable and full blood count, routine biochemical screen, glucose tolerance test and $\mathrm{X}$-rays of chest and skull were normal. A formal water deprivation test indicated cranial diabetes insipidus. During a 6-hour period the urine output did not fall below $225 \mathrm{ml} / \mathrm{h}$ with the plasma osmolality rising from $287 \mathrm{mOsm} / \mathrm{l}$ to $299 \mathrm{mOsm} / \mathrm{l}$. Following administration of $20 \mu \mathrm{g}$ desmopressin (DDAVP) intranasally the hourly urine output dropped to $40 \mathrm{ml}$. Further investigations of hypothalamic/pituitary function were performed. Serum prolactin was $334 \mathrm{mU} / 1$ (nor-

Correspondence: A.W. Patrick M.B., Ch. B., M.R.C.P. (UK), Diabetic and Dietetic Department, Royal Infirmary, Edinburgh, EH3 9YW, UK.

Accepted: 29 March 1989 mal range $60-380 \mathrm{mU} / \mathrm{l}$ ) and a combined thyrotrophin/luteinizing hormone-releasing hormone test was normal, with peak luteinizing and follicle stimulating hormone levels of $23.8 \mathrm{U} / 1$ and $6.1 \mathrm{U} / \mathrm{h}$ respectively. Plasma cortisol rose normally following insulin-induced hypoglycaemia but the growth hor mone response was moderately blunted with a pea level of $4.7 \mathrm{mU} / 1$. A computed tomographic (CT) brain scan was not carried out at this stage. Treatment with intranasal DDAVP was initiated with an excellent symptomatic response.

Two years later she returned complaining of increasing paraesthesia in her lower limbs associated with an unsteady gait. On examination she was strikingly ataxic with spasticity, hyperreflexia and diminished vibration sensation in the lower limbs. Repeat skull X-ray, CT brain scan, metrizamide cisternography, Mantoux test and muscle biopsy were all normal. A Kveim test was negative. The CSF total protein level was elevated at $1060 \mathrm{mg} / \mathrm{l}$ (normal range $200-400 \mathrm{mg} / \mathrm{l}$ ) with a normal IgG index of 0.39 (normal $<0.60$ ). A provisional diagnosis of cerebral sarcoidosis was made and the patient received a trial of steroids with no clinical response. She died suddenly 26 months after initial presentation.

At autopsy there was no evidence of sarcoidosis. Multiple tumours were present in the thalamus, cerebellum, cingulate gyri and hypothalamus. Microscopically these tumours consisted of fusiform cells of a histiocytic type, arranged in discrete lobulated masses, and the appearances were those of a diffuse cerebral lymphoma. The pituitary gland was histologically normal and no other tumours were present outwith the central nervous system.

(C) The Fellowship of Postgraduate Medicine, 1989 


\section{Discussion}

Some controversy has surrounded the classification of this rare neoplasm which accounts for approximately $1 \%$ of cerebral tumours, ${ }^{1}$ with a male preponderance ${ }^{2,3}$ and a peak incidence in the 5th and 6th decades, ${ }^{2,4}$ but the term primary cerebral lymphoma now largely supersedes older terminology including microgliomatosis and reticulum cell sarcoma, as recent studies using immunological markers have shown that many such tumours could not be derived from cells of the monocyte/phagocyte series. ${ }^{5,6}$ Response to steroids may occur ${ }^{7,8}$ but our patient did not improve clinically whilst taking oral prednisolone in a dose of up to 40 mg daily.

In most reported cases of primary cerebral lymphoma the clinical course is one of rapid deterioration similar to that seen with glioblastoma multiforme. ${ }^{1,2}$ Our case is therefore unusual in the protracted nature of the history, with symptoms suggestive of diabetes insipidus some 10 years prior to her death, although the diagnosis was not confirmed until a later stage. It is

\section{References}

1. Schaumburg, H.H., Plank, C.R. \& Adams, R.D. The reticulum cell sarcoma - microglioma group of brain tumours. A consideration of their clinical features and therapy. Brain 1972, 95: 199-212.

2. Henry, J.M., Heffner, R.R. Jr., Dillard, S.H., Earle, K.M. \& Davis, R.L. Primary malignant lymphomas of the central nervous system. Cancer 1974, 34: 1293-1302.

3. Samuelsson, S.M., Werner, I., Ponten, J, et al. Reticulo endothelial (perivascular) sarcoma of the brain. Acta Neurol Scand 1966, 42: 567-580.

4. Russell, D.S. \& Rubenstein, L.J. Pathology of Tumours of the Nervous System, 4th edition. Edward Arnold, London, 1977, pp. 105-111. of course impossible to prove that the association between diabetes insipidus and the later development of primary cerebral lymphoma was not coincidental, but this seems unlikely in view of the finding at autopsy of hypothalamic tumour deposits.

Post-mortem series have shown that hypothalamic involvement in primary cerebral lymphoma is not uncommon and panhypopituitarism associated with a hypothalamic tumour deposit has been reported. ${ }^{1}$ However, our patient had evidence of cranial diabetes insipidus with otherwise minimal abnormality of hypothalamic/pituitary function and this has not been reported previously as a presentation of primary cerebral lymphoma.

\section{Acknowledgement}

We thank Miss Carolyn Mackay for typing the manuscript.

5. Taylor, C.R., Russell, R., Lukes, R.J. \& Davis, R.L. An immunohistological study of immunoglobulin content of primary central nervous system lymphomas. Cancer 1978, 41: 2197-2205.

6. Lukes, R.J. \& Collins, R.D. New approaches to the classification of the lymphomata. Br J Cancer 1975, 31 (Suppl 2) : 1-28.

7. Williams, R.S., Cromwell, R.M., Fisher, C.M. et al. Clinical and radiological remission in reticulum cell sarcoma of the brain. Arch Neurol 1979, 36: 206-210.

8. Vaquero, J., Martinez, R., Rossi, E. \& Lopez, R. Primary cerebral lymphoma: the "ghost-tumour". Case report. $J$ Neurosurg 1984, 60: 174-176.

을

